\title{
The use of pre-emergence herbicides in cassava decreases the need of manual weeding ${ }^{1}$
}

\author{
Antonio Dias Santiago ${ }^{2}$, Sergio de Oliveira Procópio ${ }^{3}$, Guilherme Braga Pereira Braz ${ }^{4 *}$ (D), \\ Camila Jorge Bernabé Ferreira ${ }^{4}$
}

$10.1590 / 0034-737 X 202067030008$

\begin{abstract}
Weed management consists of a fundamental practice in cassava, with mechanical and chemical control widely used. The objective of this work was to evaluate the efficacy of pre-emergence herbicides, as well as to determine the interaction of these with weeding complementation in the weed management in cassava. Two experiments were conducted in Junqueiro (Alagoas). In 2015/16, the experimental design was based on randomized blocks, with treatments distributed in a split-split-plot scheme, with four replications. In the main plot, four pre-emergence associations of clomazone + flumioxazin in different doses were evaluated, in addition to a control without herbicide. In the subplots, the Caravela and Pretinha cassava cultivars were evaluated, while in the sub-subplots the control complementation was evaluated using or not the manual weeding. In the 2016/17, the plot design and layout remained the same as for 2015/16, except for the composition of the herbicide treatments, since the standardization of clomazone dose has been chosen, varying only the doses of flumioxazin. The association of clomazone and flumioxazin has shown efficacy in weed control, with a greater residual as higher doses are used. This association provided higher shoot and root yield. Weeding complementation along the cassava cycle can increase its yield.
\end{abstract}

Keywords: weed community; chemical control; integrated weed management; Manihot esculenta.

\section{INTRODUCTION}

Cassava (Manihot esculenta) possesses a high socioeconomic importance in Brazil, since its commercial exploitation, whether in family farming or in a business system, generates jobs and constitutes an important source of income for producers who are involved in its production (Santiago et al., 2018). The wide adaptation that cassava displays in relation to its cultivation in the different regions of the country is due to the fact that Brazil is designated as the center of origin of the specie (Vieira et al., 2011).

Throughout the crop cycle, a series of factors can negatively influence the development of the plants, which are subdivided into those of abiotic origin, which are related to the edaphoclimatic factors occurring during cassava cultivation, and those of biotic origin, where infection by disease-causing microorganisms, pest occurrence and weed interference are listed. In relation to the biotic factors, it is worth noting that the coexistence of the crop with the weed community has been the main limiting factor for obtaining high yields in the Brazilian cassava cultivation (Albuquerque et al., 2008, Pereira et al., 2012).

In areas where the weed growth in cassava fields is not controlled, yield reductions can reach values close to $70 \%$ (Peressin \& Carvalho, 2002). It is worth mentioning that the reduction of cassava production will depend on factors related to the crop, such as line spacing, planting density and cultivar, as well as the weed species present in the area. In addition to the reduced production of cassava roots due to interference from the weed community, the damage caused by weeds is also observed in the crop

\footnotetext{
Submitted on March 07 $7^{\text {th }}, 2019$ and accepted on May 15 th, 2020.

'Research developed by supervision of Embrapa Tabuleiros Costeiros aiming to attend a regional demand of information.

${ }^{2}$ Embrapa Tabuleiros Costeiros, Rio Largo, Alagoas, Brasil. antonio.santiago@embrapa.br;

${ }^{3}$ Embrapa Tabuleiros Costeiros, Aracaju, Sergipe, Brasil. procopio.so@gmail.com

${ }^{4}$ Universidade de Rio Verde, Rio Verde, Goiás, Brasil. guilhermebrag @ gmail.com; camilajbferreira@gmail.com

"Corresponding author: guilhermebrag@gmail.com
} 
shoot, with the lower accumulation of dry mass, which compromises the photosynthetic process and reduces the amount of vegetative material to be used in new planting (Oliveira et al., 2010).

In this context, the weed management in cassava crop is highly required, where the possibility of integration of different control methods can provide reductions in the cost of implementing the management, in addition to making the production environment more sustainable. There are still, in several places in the country, cassava crops in which weed control is exclusively performed by manual weeding, especially in those regions where subsistence agriculture is largely employed (Silva et al., 2012b). However, in recent years, due to the scarcity of labor and the high cost to use this method, many producers have adhered to the chemical control, through the application of herbicides, since this practice is easier to be performed.

Unlike other cultivated species, in which the use of herbicides in post-emergence is the most employed way of controlling weed community, the main modality employed in the chemical control of weeds in cassava has been pre-emergent herbicide applications (Silva et al., 2012a, Santiago et al., 2018). The variation in the positioning of herbicides in cassava crops is mainly due to the low number of herbicides registered for postemergence application of the crop, especially those with spectrum on dicotyledons, as well as the good selectivity that these active ingredients present when applied in cassava pre-emergence (Silva et al., 2014, Brazil, 2018).

In order to implement integrated weed management in cassava production, one possibility would be the use of pre-emergent herbicides, with possible supplementation employing manual weeding after the emergence of cassava plants. In this management system, the residual weed control, would be achieved, reducing the initial interference on the crop, and in the phase where it is most sensitive to the phytotoxic action of the herbicides, manual weeding would help in reducing the negative effect of the community weed on cassava plants.

In this way, the objective of this study was to evaluate the effectiveness of the association between clomazone and flumioxazin in pre-emergence control of weeds in the cassava crop, as well as to evaluate the interaction of this herbicide combination with the complementation with manual weeding.

\section{MATERIALAND METHODS}

Two experiments were conducted in adjacent areas located in the municipality of Junqueiro (Alagoas, Brazil), one in the 2015/16 season and another during the 2016/17 season. The geographic coordinates of the area where the experiments were installed are $09^{\circ} 55^{\prime} 31^{\prime \prime} \mathrm{S}, 36^{\circ} 28^{\prime} 33^{\prime \prime}$
$\mathrm{W}$ and $175 \mathrm{~m}$ altitude. The predominant climate in the municipality is the type As (Köppen classification), which is characterized as a tropical climate with a dry season (savannah climate), presenting a dry season in summer and rainfall in autumn/winter. The annual average temperature and precipitation is $23.7^{\circ} \mathrm{C}$ and $1034 \mathrm{~mm}$, respectively (Climate-Data, 2018). The precipitation data observed during the conduction of the experiments in both agricultural crops are presented in Figure 1.

The soil of the experimental area was classified as RedYellow Argisol (Embrapa, 2013). Before the installation of the experiments, soil samples were taken from the experimental areas, and presented the following physicochemical characteristics: 1) 2015/16 season: $\mathrm{pH}$ in $\mathrm{H}_{2} \mathrm{O}$ of $5.0 ; 2.5$ $\mathrm{cmol}_{\mathrm{c}} \mathrm{dm}^{-3}$ of $\mathrm{H}^{+}+\mathrm{Al}^{+3} ; 0.37 \mathrm{cmol}_{\mathrm{c}} \mathrm{dm}^{-3}$ of $\mathrm{Al}^{+3} ; 0.7 \mathrm{cmol}_{\mathrm{c}}$ $\mathrm{dm}^{-3}$ of $\mathrm{Ca}^{+2} ; 0.5 \mathrm{cmol}_{\mathrm{c}} \mathrm{dm}^{-3}$ of $\mathrm{Mg}^{+2} ; 29 \mathrm{mg} \mathrm{dm}^{-3}$ of $\mathrm{K}^{+} ; 24$ $\mathrm{mg} \mathrm{dm}{ }^{-3}$ of P; $0.71 \%$ of organic matter.; $185 \mathrm{~g} \mathrm{~kg}^{-1}$ of clay, $114 \mathrm{~g} \mathrm{~kg}^{-1}$ of silt, $701 \mathrm{~g} \mathrm{~kg}^{-1}$ of sand (sandy loam texture). 2) 2016/17 season: $\mathrm{pH}$ in $\mathrm{H}_{2} \mathrm{O}$ of $6.2 ; 2.6 \mathrm{cmol}_{\mathrm{c}} \mathrm{dm}^{-3}$ of $\mathrm{H}^{+}+$ $\mathrm{Al}^{+3} ; 0.11 \mathrm{cmol}_{\mathrm{c}} \mathrm{dm}^{-3}$ of $\mathrm{Al}^{+3} ; 0.8 \mathrm{cmol}_{\mathrm{c}} \mathrm{dm}^{-3}$ of $\mathrm{Ca}^{+2} ; 0.4$ $\mathrm{cmol}_{\mathrm{c}} \mathrm{dm}^{-3}$ of $\mathrm{Mg}^{+2} ; 38 \mathrm{mg} \mathrm{dm}^{-3}$ of $\mathrm{K}^{+} ; 28 \mathrm{mg} \mathrm{dm}^{-3}$ of P; $0.22 \%$ of organic matter.; $166 \mathrm{~g} \mathrm{~kg}^{-1}$ of clay, $241 \mathrm{~g} \mathrm{~kg}^{-1}$ of silt, $593 \mathrm{~g} \mathrm{~kg}^{-1}$ of sand (sandy loam texture).

Prior to the planting, the soil was prepared by means of a plowing followed by two harrows. After soil preparation, furrows of $15 \mathrm{~cm}$ depth were mechanically opened, spaced $1.0 \mathrm{~m}$ apart. For the planting, $20 \mathrm{~cm}$ maniocs were used, positioned $10 \mathrm{~cm}$ depth, spacing one from the other at $60 \mathrm{~cm}$ in the planting line. In the planting, fertilization was performed in the furrow using the equivalent of $18 \mathrm{~kg} \mathrm{ha}^{-1}$ of urea $(45 \%$ of $\mathrm{N})+70 \mathrm{~kg} \mathrm{ha}^{-1}$ of potassium chloride $\left(60 \%\right.$ of $\left.\mathrm{K}_{2} \mathrm{O}\right)$. A cover fertilization was also performed at 45 days after planting, providing the equivalent of $73 \mathrm{~kg} \mathrm{ha}^{-1}$ of urea $(45 \% \mathrm{~N})$. The techniques described for soil preparation, planting, basic fertilization and cover fertilization were used in both experiments.

The first experiment was installed on June 15, 2015. The experiment was based on a complete randomized block design, with treatments distributed in a split-splitplot scheme, with four replications. In the main plot, four associations of the clomazone and flumioxazin herbicides applied in cassava pre-emergence $(540+40 ; 1080+80$; $1620+120 ; 2160+160 \mathrm{~g} \mathrm{ha}^{-1}$ ) were evaluated, in addition to a control without herbicide application during the whole cycle. In the subplots, two cassava cultivars that present a wide area of planting in the Agreste of the Alagoas, Caravela and Pretinha cassava were evaluated. In the subsubplot it was evaluated the complementation, and the absence of it, of weed control by three manual weeding, the first one being at 50 days after planting (DAP), the second at 100 DAP and third at 150 DAP.

The sub-subplots had four lines planted with $6 \mathrm{~m}$ long cassava roots, which were spaced apart at $1.0 \mathrm{~m}$ (total area 
$=24.0 \mathrm{~m}^{2}$ ). The useful area for evaluation corresponded to the two central lines, subtracting $0.5 \mathrm{~m}$ from the initial and final end of the sub-subplot (useful area $=10 \mathrm{~m}^{2}$ ).

The second experiment was installed on July 13, 2016. The experimental design, as well as the arrangement of the plots were the same of that described before for the first experiment. The only exception was the composition of the herbicide treatments evaluated in the main plot, as it was decided, in the second experiment, by the standardization of the clomazone, varying only the dose of flumioxazin, since the main problem of weeds in cassava in the investigated region are the broad leaves. The herbicide treatments evaluated in the second experiment were composed by the association between clomazone at a constant dose (1260 $\left.\mathrm{g} \mathrm{ha}^{-1}\right)$ and flumioxazin at doses of 40, 80, 120 and $160 \mathrm{~g} \mathrm{ha}^{-1}$. For subplots and sub-subplots, the performed evaluations followed the same description presented for the first experiment.

The applications of the treatments in both experiments were performed one day after the planting of cassava, consisting, therefore, in pre-emergence applications of the cassava crop and of the weeds. For all applications, a constant pressure sprayer was used, equipped with a bar with eight XR 110.02 (fan-type) tips, spaced $0.5 \mathrm{~m}$ apart, providing an application volume equivalent to $160 \mathrm{~L} \mathrm{ha}^{-1}$.

In both experiments, the visual percentage of weed control was evaluated at 80 and 100 days after application of the herbicides (DAA), in the first experiment, and at 30 and $95 \mathrm{DAA}$, in the second experiment. In these evaluations, infestation of the area based on weed samplings in the control without herbicide and without weeding was used as a reference. The types of weed evaluated in the first study were Benghal dayflower (Commelina benghalensis), Indian heliotrope (Heliotropium indicum), Largeflower Mexican clover (Richardia grandiflora) and "erva-palha" (Blainvillea rhomboidea); and in the second experiment $C$. benghalensis, "malva-rasteira" (Pavonia cancellata), Perennial Pigweed (Amaranthus deflexus), R. grandiflora, B. rhomboidea, "mussambê" (Cleome affinis) and sida (Sida spp.). In the control evaluation, a percentage scale (0-100\%) has been employed, where $0 \%$ means absence of symptoms and $100 \%$ denotes for the death of all plants (SBCPD, 1995). For the control efficacy results, the average results promoted by the herbicide treatment were presented, excluding the factors cassava cultivar and complementation with manual weeding.

The crop phytotoxicity was evaluated in both experiments at the same dates of the weed control evaluations, by means of a percentage scale, in which $0 \%$ means absence of symptoms and $100 \%$ denotes for death of the plants. In this evaluation, the complementation with manual weeding was again not considered. At the time of harvesting, which occurred 15 months after the beginning of the experiments, the following response-variables were evaluated: plant shoot green weight $\left(\mathrm{Mg} \mathrm{ha}^{-1}\right)$ and cassava root yield $\left(\mathrm{Mg} \mathrm{ha}^{-1}\right)$.

Statistical analyzes were performed using the Sisvar software (Ferreira, 2011). All data were submitted to analysis of variance. When a significant effect was observed between the tested factors or between the levels of each factor, the means were compared by the LSD Fisher test $(\mathrm{p} \leq 0.05)$.

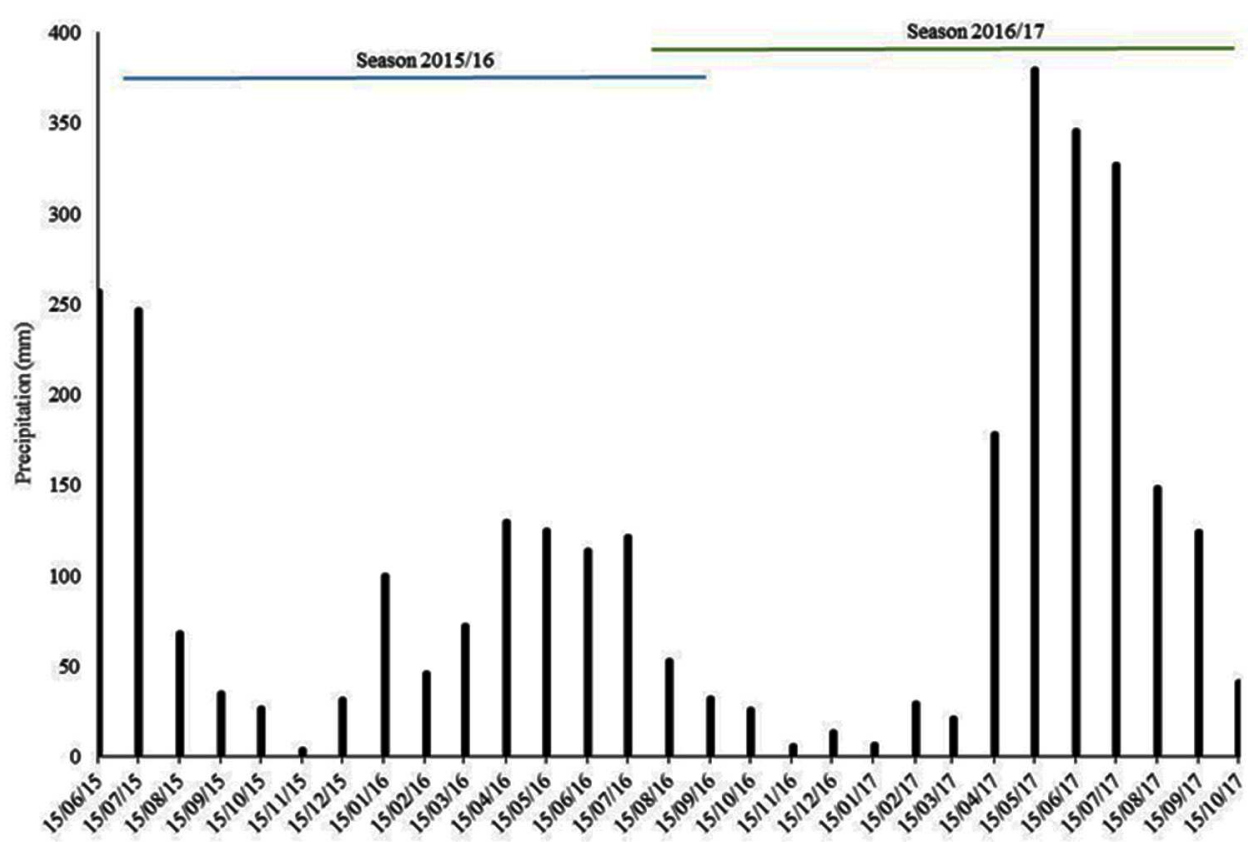

Figure 1: Precipitation data (mm) during the period of conduction of the experiments. Junqueiro (Alagoas, Brazil), 2015/16 and 2016/17. 


\section{RESULTS AND DISCUSSION}

The results of weed control evaluations caused by treatment with pre-emergence herbicides on cassava are presented in Tables 1 and 2, which presents data for the 2015/16 and 2016/17 seasons, respectively. In the first case, the association between clomazone and flumioxazin, in the two highest evaluated dosages, consisted of the treatments that promoted the most prominent control levels on C. benghalensis, and this result persisted up to 100 DAA (Table 1).

Regarding the species $R$. grandiflora and $B$. rhomboidea, it was found that all clomazone and flumioxazin combinations were effective in the control of these weeds, regardless of the dose of each herbicide employed in the combination (Table 1). Regarding H. indicum, although all doses of the combination between clomazone and flumioxazin provided control levels above $80 \%$ until the 100 DAA, it was verified that the use of these herbicides in doses higher than $1080+80 \mathrm{~g} \mathrm{ha}^{-1}$, for clomazone and flumioxazin, respectively, has provided better management performance of the above-mentioned weed.

In the experiment conducted in the $2016 / 17$ season, for the $C$. benghalensis, $P$. cancellata, $R$. grandiflora, B. rhomboidea and Sida sp. species, it can be seen at 30 DAA that there was no statistical difference between the combinations of clomazone + flumioxazin, regarding the performance in the control of these weeds (Table 2 ). It is worth mentioning that, despite the similarity in terms of the efficacy of the different treatments in the control of these species, for $C$. benghalensis and $P$. cancellata, the association between clomazone and flumioxazin at the lowest dose $\left(1260+40 \mathrm{~g} \mathrm{ha}^{-1}\right)$ have not reached $80 \%$ of weed inhibition, a threshold considered as a limiting percentage for herbicide registration in Brazil (SBCPD, 1995).

Regarding the evaluation performed at 30 DAA, the two highest doses of the association between clomazone + flumioxazin displayed superior performance in the control of $C$. affinis when compared to the treatment in which these herbicides were applied at lower doses (Table 2).

In the final control evaluation performed at the 95 DAA, it was verified that, for the species $C$. benghalensis, $B$. rhomboidea, and $C$. affinis, there were no differences in the performance of the herbicide associations at different doses aiming at the suppression of these weeds (Table 2). However, for $C$. benghalensis, the obtained control levels were lower than those considered acceptable for the chemical management of the weed community in the cassava crop, especially in the three lower doses of the association between clomazone + flumioxazin.

For the A. deflexus, no difference has been observed between herbicide treatments, since all the proportions of the association between clomazone and flumioxazin were able to inhibit the emergence of this weed in the treated plots (data not shown).

In relation to the results of the 2016/17 season for $P$. cancellata, the pre-emergence application of the association between clomazone (1260 $\mathrm{g} \mathrm{ha}^{-1}$ ) and flumioxazin (120 or $160 \mathrm{~g} \mathrm{ha}^{-1}$ ), resulted in the best combination for the control of the weed (Table 2). Finally, for $R$. grandiflora and Sida sp., all the combinations between the herbicides demonstrated the potential to be used in the residual management of these species in cassava plantations, except for the lowest dose of the association between clomazone + flumioxazin (Table 2).

Table 1: Control percentage of different weed species infesting the cassava crop. Junqueiro (Alagoas, Brazil), 2015/16

\begin{tabular}{|c|c|c|c|c|}
\hline \multirow{2}{*}{ Treatment $\left(\mathrm{g} \mathrm{ha}^{-1}\right)$} & \multicolumn{4}{|c|}{ Control (\%) - 80 DAA } \\
\hline & C. benghalensis & R. grandiflora & B. rhomboidea & H. indicum \\
\hline Clomazone + flumioxazin $(540+40)$ & $64 \mathrm{~b}$ & $91 \mathrm{a}$ & $93 \mathrm{a}$ & $85 \mathrm{~b}$ \\
\hline Clomazone + flumioxazin $(1080$ + 80) & $68 \mathrm{~b}$ & $93 \mathrm{a}$ & $94 \mathrm{a}$ & $94 \mathrm{ab}$ \\
\hline Clomazone + flumioxazin $(1620+120)$ & $86 \mathrm{a}$ & $95 \mathrm{a}$ & $98 \mathrm{a}$ & $98 \mathrm{a}$ \\
\hline Clomazone + flumioxazin $(2160+160)$ & $90 \mathrm{a}$ & $100 \mathrm{a}$ & $100 \mathrm{a}$ & $100 \mathrm{a}$ \\
\hline Control without herbicide & $0 \mathrm{c}$ & $0 \mathrm{~b}$ & $0 \mathrm{~b}$ & $0 \mathrm{c}$ \\
\hline \multirow[t]{3}{*}{$\mathrm{CV}(\%)$} & 10.4 & 12.9 & 8.9 & 10.3 \\
\hline & \multicolumn{4}{|c|}{ Control $(\%)$ - 100 DAA } \\
\hline & C. benghalensis & R. grandiflora & B. rhomboidea & H. indicum \\
\hline Clomazone + flumioxazin $(540+40)$ & $63 \mathrm{~b}$ & $89 \mathrm{a}$ & $85 \mathrm{a}$ & $83 \mathrm{~b}$ \\
\hline Clomazone + flumioxazin $(1080+80)$ & $67 \mathrm{~b}$ & $90 \mathrm{a}$ & $86 \mathrm{a}$ & $89 \mathrm{ab}$ \\
\hline Clomazone + flumioxazin $(1620+120)$ & $85 \mathrm{a}$ & $94 \mathrm{a}$ & $96 \mathrm{a}$ & $96 \mathrm{ab}$ \\
\hline Clomazone + flumioxazin $(2160+160)$ & $88 \mathrm{a}$ & $100 \mathrm{a}$ & $100 \mathrm{a}$ & 99 a \\
\hline Control without herbicide & $0 \mathrm{c}$ & $0 \mathrm{~b}$ & $0 \mathrm{~b}$ & $0 \mathrm{c}$ \\
\hline $\mathrm{CV}(\%)$ & 14.6 & 13.3 & 17.7 & 13.9 \\
\hline
\end{tabular}

Results followed by the same letters in the column do not differ from each other according to the Fisher LSD test (p $\leq 0.05$ ).

Rev. Ceres, Viçosa, v. 67, n.3, p. 223-230, may/jun, 2020 
Comparing the control performances obtained by the association of the clomazone and flumioxazin herbicides in the two crops in which the experiments were conducted, it was verified that for a greater residual control, it is necessary to use higher doses of clomazone for some species, as can be observed for $C$. benghalensis. The efficacy of clomazone in the pre-emergence management of the above-mentioned weed has already been reported in the literature, for potato crop, however it has been shown a low extent of residual control of the weed due to the employed herbicide doses (Luz et al., 2018). In cassava crop, which tolerates higher doses of clomazone, the efficacy of this compound against $C$. benghalensis has already been observed, when the herbicide is associated with flumioxazin, metribuzin or ametryn (Costa et al., 2015, Santiago et al., 2018).

In the 2015/16 season, no symptoms of phytointoxication of cassava were observed due to the application of pre-emergence herbicides (data not shown). On the other hand, in the experiment conducted in the following season (2016/17), injuries caused by phytotoxic action of herbicides in all treatments at 30 DAA were observed, especially those in which higher flumioxazin doses were used, associated with clomazone, which caused more pronounced symptoms in cassava plants (Table 3). At 95 DAA, herbicide injures were no longer observed.

The above-mentioned behavior may be attributed to differences in rainfall distribution between the two crops in which the experiments were conducted. Although during the 2016/17 crop it was observed a higher precipitation volume than in the previous season considering the whole crop cycle, during the first month of cassava development, there was a lower amount of rain ( $60 \%$ lower) if compared with the $2015 / 16$ season (Figure 1). This fact may have contributed to a slower degradation of the herbicides, which contributed to the occurrence of injuries in the cassava seedlings.

Still in relation to the phytointoxication levels observed in the 2016/17 season, it is verified in the evaluation carried out at 30 DAA, that regardless of the planted cassava cultivar, as the applied dose of flumioxazin combined with clomazone was increased, greater injuries were found. This information demonstrates that even flumioxazin shows selectivity for cassava crop (Santiago et al., 2018), caution should be exercised when recommending higher doses of this herbicide. Comparing the tolerance between the two cassava cultivars, apparently, the cultivar "Caravela" demonstrates to show a little more tolerance than "Pretinha", since there was a differential response in the two highest doses of the association between clomazone + flumioxazin.

Table 4 presents the data of the shoot dry weight of cassava plants, observing that, in this case, a significant effect of the isolated factors evaluated in the experiments was observed in both seasons. In relation to the effect of the association between clomazone + flumioxazin, in the 2015/16 season, the combination of these herbicides in the two higher doses, provided greater accumulation of dry weight in relation to the plants that were studied in the plots where the two lower doses of the herbicide combinations were applied.

Nevertheless, in all cases where pre-emergence herbicides in cassava were used, higher dry weight values were observed, if compared with the control sample. This fact demonstrates the importance of the use of residual

Table 2: Control percentage of different weed species infesting the cassava crop. Junqueiro (Alagoas, Brazil), 2016/17

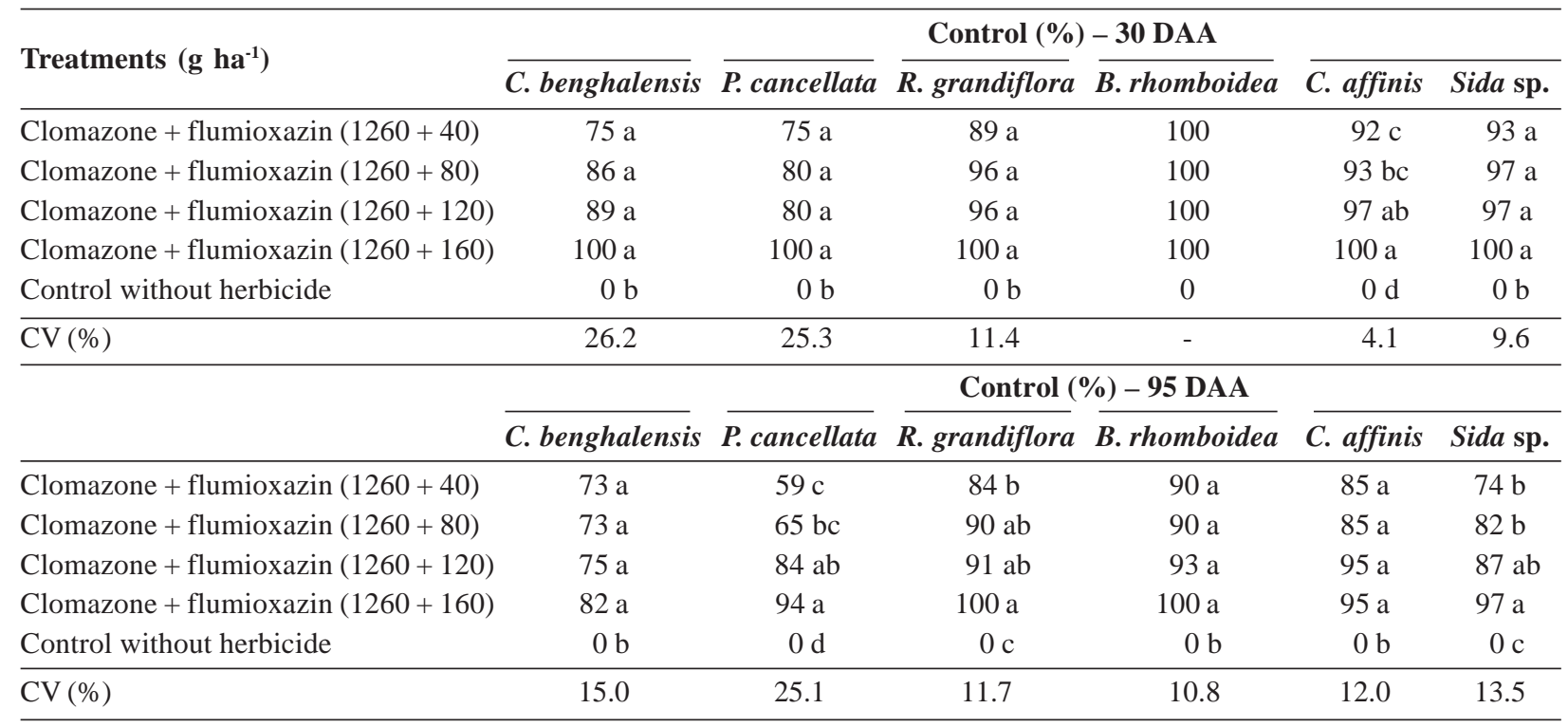

Means followed by distinct lowercase letters in the column differ according to the Fisher LSD test (p $\leq 0.05)$. 
herbicides in order to reduce the interference of the weed community in the crop. As for the 2016/17 season, no significant difference was observed between the doses evaluated for the association between clomazone and flumioxazin.

Regardless of the season in which the experiments were conducted, it was observed that the cassava cultivar "Pretinha" had a higher shoot dry weight than the cultivar "Caravela" (Table 4). This behavior may be related to variations in the morphophysiological characteristics between the two cultivars. In a previous study conducted by Santiago et al. (2018), it was observed that the cultivar "Pretinha" presented lower sensitivity to weed interference if compared with "Caravela", which has been attributed to the more vigorous growth that the former cultivar presents. This may be one of the reasons to explain the higher shoot dry weight values for the cultivar "Pretinha".
Finally, cassava plants developed in the plots that received manual weeding complementation had higher values of dry weight in comparison with those in which this type of management of the weed community was not used. In the literature, there are reports that weed interference in cassava not only affects root yield, but also limits the growth of plant shoots (Silva et al., 2012b). Such observation strengthens the need to manage the weed community in cassava crop, so that this practice should be carefully employed by producers, since the shoots of cassava provide material for vegetative propagation in new plantations, besides being used for the production of fodder for the use in animal feed (Albuquerque et al., 2008).

For root yield, no effect of triple interaction between herbicide, cultivars and complementation of weed control in post-emergence has been observed. The only seen effects were those of the interaction between the

Table 3: Percentages of phytointoxication of cassava plants as a function of herbicide application in pre-emergence of the crop. Junqueiro (Alagoas, Brazil), 2016/17

\begin{tabular}{|c|c|c|c|c|}
\hline \multirow{3}{*}{ Treatment ( $\left.\mathrm{g} \mathrm{ha}^{-1}\right)$} & \multicolumn{4}{|c|}{ Phytointoxication (\%) } \\
\hline & \multicolumn{2}{|c|}{30 DAA } & \multicolumn{2}{|c|}{95 DAA } \\
\hline & Caravela & Pretinha & Caravalea & Pretinha \\
\hline Clomazone + flumioxazin $(1260+40)$ & $9.5 \mathrm{Ad}$ & $10.3 \mathrm{Ad}$ & 0 & 0 \\
\hline Clomazone + flumioxazin $(1260+80)$ & $14.8 \mathrm{Ac}$ & $16.0 \mathrm{Ac}$ & 0 & 0 \\
\hline Clomazone + flumioxazin $(1260+120)$ & $20.5 \mathrm{Bb}$ & $23.3 \mathrm{Ab}$ & 0 & 0 \\
\hline Clomazone + flumioxazin $(1260+160)$ & $25.0 \mathrm{Ba}$ & $30.3 \mathrm{Aa}$ & 0 & 0 \\
\hline Control without herbicide & $0.0 \mathrm{Ae}$ & $0.0 \mathrm{Ae}$ & 0 & 0 \\
\hline
\end{tabular}

Means followed by distinct uppercase letters in the row and lowercase letters in the column differ according to the Fisher LSD test (p $\leq$ $0.05)$.

Table 4: Shoot dry weight as a function of the weed management applied in the cassava crop. Junqueiro (Alagoas, Brazil), 2015/16 and $2016 / 17$

\begin{tabular}{|c|c|c|c|}
\hline \multicolumn{4}{|c|}{ Shoot dry weight $\left(\mathrm{Mg} \mathrm{ha}^{-1}\right)$} \\
\hline Treatments $\left(\mathrm{g} \mathrm{ha}^{-1}\right)$ & $2015 / 16$ & Treatments $\left(\mathrm{g} \mathrm{ha}^{-1}\right)$ & 2016/17 \\
\hline Clomazone + flumioxazin $(540+40)$ & $10.6 \mathrm{~b}$ & Clomazone + flumioxazin $(1260+40)$ & $6.3 \mathrm{ab}$ \\
\hline Clomazone + flumioxazin $(1080+80)$ & $11.0 \mathrm{~b}$ & Clomazone + flumioxazin $(1260+80)$ & $7.7 \mathrm{a}$ \\
\hline Clomazone + flumioxazin $(1620+120)$ & $13.1 \mathrm{a}$ & Clomazone + flumioxazin $(1260+120)$ & $7.1 \mathrm{a}$ \\
\hline Clomazone + flumioxazin $(2160+160)$ & $13.2 \mathrm{a}$ & Clomazone + flumioxazin $(1260+160)$ & $7.8 \mathrm{a}$ \\
\hline Control without herbicide & $6.1 \mathrm{c}$ & Control without herbicide & $5.0 \mathrm{~b}$ \\
\hline \multicolumn{4}{|l|}{ Cultivars } \\
\hline Caravela & $10.2 \mathrm{~b}$ & & $6.1 \mathrm{~b}$ \\
\hline Pretinha & $11.5 \mathrm{a}$ & & $7.4 \mathrm{a}$ \\
\hline \multicolumn{4}{|l|}{ Complementation with manual weeding } \\
\hline Manual weeding & $12.1 \mathrm{a}$ & & $7.4 \mathrm{a}$ \\
\hline No manual weeding & $9.6 \mathrm{~b}$ & & $6.1 \mathrm{~b}$ \\
\hline $\mathrm{CV}_{\text {average }}(\%)$ & 23.5 & & 32.1 \\
\hline
\end{tabular}

Means followed by distinct lowercase letters in the column differ according to the Fisher LSD test ( $\mathrm{p} \leq 0.05$ ).

Rev. Ceres, Viçosa, v. 67, n.3, p. 223-230, may/jun, 2020 
Table 5: Root yield in cassava crop as a function of weed management. Junqueiro (Alagoas, Brazil), 2015/16 and 2016/17

\begin{tabular}{|c|c|c|}
\hline \multirow{2}{*}{ Treatments $\left(\mathrm{g} \mathrm{ha}^{-1}\right)$} & \multicolumn{2}{|c|}{ Root yield (Mg ha' $\left.{ }^{-1}\right)$ - 2015/16 } \\
\hline & Manual weeding & No manual weeding \\
\hline Clomazone + flumioxazin $(540+40)$ & $24.4 \mathrm{Aa}$ & $18.4 \mathrm{Bb}$ \\
\hline Clomazone + flumioxazin $(1080+80)$ & $25.2 \mathrm{Aa}$ & $20.0 \mathrm{Bab}$ \\
\hline Clomazone + flumioxazin $(1620+120)$ & $25.1 \mathrm{Aa}$ & $22.3 \mathrm{Aab}$ \\
\hline Clomazone+ flumioxazin $(2160+160)$ & $25.7 \mathrm{Aa}$ & $23.7 \mathrm{Aa}$ \\
\hline Control without herbicide & $16.1 \mathrm{Ab}$ & $3.1 \mathrm{Bc}$ \\
\hline \multirow[t]{2}{*}{$\mathrm{CV}(\%)$} & \multicolumn{2}{|c|}{20.8} \\
\hline & \multicolumn{2}{|c|}{ Root yield $\left(\mathrm{Mg} \mathrm{ha}^{-1}\right)-2016 / 17$} \\
\hline Clomazone + flumioxazin $(1260+40)$ & $19.5 \mathrm{Aa}$ & $13.6 \mathrm{Ba}$ \\
\hline Clomazone + flumioxazin $(1260+80)$ & $21.0 \mathrm{Aa}$ & $18.1 \mathrm{Aa}$ \\
\hline Clomazone + flumioxazin $(1260+120)$ & $19.7 \mathrm{Aa}$ & $17.0 \mathrm{Aa}$ \\
\hline Clomazone + flumioxazin $(1260+160)$ & $20.9 \mathrm{Aa}$ & $17.9 \mathrm{Aa}$ \\
\hline Control without herbicide & $16.6 \mathrm{Aa}$ & $6.4 \mathrm{Bb}$ \\
\hline
\end{tabular}

$\begin{array}{ll}\mathrm{CV}(\%) & 25.8\end{array}$

Means followed by distinct uppercase letters in the row and lowercase letters in the column differ according to the Fisher LSD test $(\mathrm{p} \leq 0.05)$.

treatments applied in pre-emergence and the complementation with manual weeding (Table 5). The behavior described above was observed in both agricultural seasons in which the experiments were performed.

In the 2015/16 season, it was observed that, regardless of the presence or absence of manual weeding complementation after emergence of cassava, when the association between the herbicides clomazone + flumioxazin was used, higher cassava root production was observed (Table 5). It is also important to highlight the use of higher doses of herbicides $\left(2160+160 \mathrm{~g} \mathrm{ha}^{-1}\right)$ in the plots where the manual weeding was not performed. Such herbicide treatments have demonstrated superiority over the one in which it was used the lowest dose of association between clomazone and flumioxazin $\left(540+40 \mathrm{~g} \mathrm{ha}^{-1}\right)$.

In the first season, the effect of complementing the management of the weed community with manual weeding was observed, and this practice is fundamental when employing the two lower doses of the combination of clomazone + flumioxazin (Table 5). In addition, it was verified that the use of manual weeding to control weeds, without the use of herbicides in pre-emergence of the crop, was able to provide an increase in yield equivalent to 13 $\mathrm{Mg} \mathrm{ha}^{-1}$.

In the 2016/17 season, it has been observed a distinct behavior in relation to the first experiment, especially in relation to the treatments in which weeding complementation was performed in the control of the weed community. In these treatments, the use of pre-emergence herbicides of cassava have not provided increase in root yield in relation to the control where only manual weeding was performed.

\section{CONCLUSIONS}

The association between clomazone and flumioxazin have shown broad efficacy in the chemical management of weeds in cassava crop, with a greater extent of residual control as higher doses are used.

The use of the combination between clomazone and flumioxazin herbicides provides higher values of dry shoot weight and root yield, regardless of the dose used in this combination, when compared to the control studies.

\section{ACKNOWLEDGMENTS}

The authors gratefully acknowledge the Fundação de Amparo à Pesquisa do Estado de Alagoas (FAPEAL) for the financial support, which promoted the execution of this study.

There is no conflict of interest between the authors in the publication of this work.

\section{REFERENCES}

Albuquerque JAA, Sediyama T, Silva AA, Carneiro JES, Cecon PR \& Alves JMA (2008) Interferência de plantas daninhas sobre a produtividade da mandioca (Manihot esculenta). Planta Daninha, 26:279-289.

BRASIL (2018) Ministério da Agricultura, Pecuária e Abastecimento. Sistema de Agrotóxicos Fitossanitários/Agrofit. Available at: <http://www.agricultura.gov.br/servicos-e-sistemas/sistemas/ agrofitl>. Accessed on: January 21 2018.

CLIMATE-DATA (2018) Clima junqueiro. Available at: <https:// pt.climate-data.org/america-do-sul/brasil/alagoas/junqueiro43044/>. Accessed on: January 18 $18^{\text {th }}, 2018$.

Costa NV, Ramella JRP, Sontag DA, Pavan GC \& Dourado RF (2015) Flumioxazin and S-metolachlor efficiency and selectivity in pre-emergence application of cassava 'Baianinha'. Revista Brasileira de Herbicidas, 14:228-234. 
Embrapa - Empresa Brasileira de Pesquisa Agropecuária (2013) Sistema brasileiro de classificação de solos. $3^{\text {a }}$ ed. Brasília Embrapa Solos. 353p.

Ferreira DF (2011) Sisvar: a computer statistical analysis system. Ciência e Agrotecnologia, 35:1039-1042.

Luz JMQ, Fonseca LF \& Duarte IN (2018) Selectivity of preemergence herbicides in potato cv. Innovator. Horticultura Brasileira, 36:223-228.

Oliveira SP, Viana AES, Matsumoto SN, Cardoso Júnior NS, Sediyama T \& José ARS (2010) Efeito da poda e de épocas de colheita sobre características agronômicas da mandioca. Acta Scientiarum - Agronomy, 32:99-108.

Pereira GAM, Lemos VT, Santos JB, Ferreira EA, Silva DV, Oliveira MC \& Menezes CWG (2012) Crescimento da mandioca e plantas daninhas em resposta à adubação fosfatada. Revista Ceres, 59:716-722.

Peressin VA \& Carvalho JEB (2002) Manejo integrado de plantas daninhas em mandioca. In: Cereda MP (Ed.) Cultura de Tuberosas Amiláceas Latino Americanas. São Paulo, Fundação Cargill p.302-349
Santiago AD, Cavalcante MHB, Braz GBP \& Procópio SO (2018) Efficacy and selectivity of herbicides applied in cassava preemergence. Revista Caatinga, 31:640-650.

Silva DV, Silveira HM, Alves, EA, Carvalho FP, Castro Neto MD, Silva AA \& Sediyama T (2014) Aspectos fisiológicos da mandioca após a aplicação dos herbicidas fluazifop-p-butil e fomesafen. Revista Ceres, 61:178-183.

Silva DV, Santos JB, Carvalho FP, Ferreira EA, França AC, Fernandes JSC, Gandini EMM \& Cunha VC (2012a) Seletividade de herbicidas pós-emergentes na cultura da mandioca. Planta Daninha, 30:835-841.

Silva DV, Santos JB, Ferreira EA, Silva AA, França AC \& Sediyama T (2012b) Manejo de plantas daninhas na cultura da mandioca. Planta Daninha, 30:901-910.

SBCPD - Sociedade Brasileira da Ciência das Plantas Daninhas (1995) Procedimentos para instalação, avaliação e análise de experimentos com herbicidas. Londrina, SBCPD. 42p.

Vieira EA, Fialho JF, Faleiro FG, Bellon G \& Silva MS (2011) Caracterização molecular de acessos de mandioca biofortificados com potencial de uso no melhoramento genético. Revista Ciência Agronômica, 42:457-463. 